\title{
Reversibility of Hypertensive Vascular Changes after Coarctation Repair in Dogs
}

\author{
M. LESKINEN, A. REINILÄ, M. TARKKA, AND M. UHARI \\ Departments of Physiology, Pathology, Surgery, and Paediatrics, University of Oulu, Finland
}

\begin{abstract}
A silk ligature was tied around the aorta at the site of the ligamentum arteriosum in beagle puppies aged $8 \mathrm{wk}$, and the aortic coarctation was corrected $8 \mathrm{mo}$ later, when the aortic peak-to-peak systolic pressure gradient was 6.0 (SD 0.7) $\mathrm{kPa}$. Similar thoracotomy was performed as a sham operation on the control animals on both occasions. One y after the coarctation repair, there was practically no systolic pressure gradient across the aortoplasty site at rest [0.5 (1.0) $\mathrm{kPa}$. Histologic examination $12 \mathrm{mo}$ after the correction operation showed the medial and intimal layers of the aortic arch in the aortoplasty group $(n=8)$ were significantly thicker than those in the control group $(n=7)$ [media $1.86(0.06)$ versus 1.78 $(0.08) \mathrm{mm}$ and intima $53.2(13.3)$ versus $38.3(10.9) \mu \mathrm{m}$, respectively, $p<0.05$ for both]. The thicknesses of both intima and media of the left anterior descending and circumflexing coronary arteries and descending aorta distal to the aortoplasty site were similar in both groups. The increased vascular wall thickness may cause reduced compliance of the vascular bed above the coarctation site and hypertension after correction of the coarctation. Our results support the finding that patients with repaired aortic coarctation have an increased risk of permanent vascular changes. (Pediatr Res 31: 297-299, 1992)
\end{abstract}

Aortic coarctation causes thickening of the intima and media of the coronary arteries in monkeys, reducing the caliber of these vessels (1). The media in the coronary arteries of coarcted dogs thickens, and the proportions of glycosaminoglycans and nuclei in it increase (2), whereas the mineralization and quantity of smooth muscle cells, elastin, and collagen and the thickening of the aortic wall are seen to increase in patients with aortic coarctation (3-5). The high blood pressure above the coarctation is the most probable pathomechanism for these vascular changes, exerting on the arterial wall a biphasic effect in which the early phase consists of smooth muscle hypertrophy and the later one is characterized by an increase in the amount of fibrous elements $(6,7)$. The aortic wall smooth muscle hypertrophy occurring in rats after short-term hypertension (3-4 wk) is reversible (8), but longer-term hypertension causes irreversible increases in vascular wall collagen and elastin $(6,9,10)$. The more severe coronary artery atherosclerotic disease with plaque formation observed in coarcted monkeys is irreversible (1).

Morbidity and mortality from atherosclerotic heart disease are high after coarctation repair $(11,12)$, but it is for the most part not known whether this is due to the irreversible hypertensive vascular changes that have taken place before coarctation repair. If the changes in the vascular walls are irreversible, they may

Received April 9, 1991; accepted October 11, 1991.

Correspondence: M. Leskinen, M.D., University of Oulu, Department of Physiology, Kajaanintie 52 A, Oulu, SF-90220, Finland.

Supported by The Paulo Foundation. cause hypertension and left ventricular hypertrophy after coarctation repair $(13,14)$. The present experiment was designed to study the reversibility of vascular changes in the aorta and coronary arteries of coarcted dogs 1 y after coarctation repair.

\section{MATERIALS AND METHODS}

Eighteen beagle puppies from four litters were randomly allocated to coarctation (10 puppies) and control groups (eight puppies). At the age of 2 mo, a juxtaductal aortic coarctation was made through the 4th intercostal space from a lateral thoracotomy by tying a silk ligature around the aorta. The ligature was accepted as tight enough when the distal aortic mean blood pressure decreased to $3.3 \mathrm{kPa}(15)$. Aortic blood pressure started to increase immediately after the constriction, and the mean arterial pressure in the descending aorta was $5.5(0.9) \mathrm{kPa}$ at the end of the operation, having been 10.8 (1.3 SD) $\mathrm{kPa}$ before the operation. A sham operation was performed in the same way, except that no ligature was left around the aorta. The coarctation was repaired by the venous patch aortoplasty method (16) at the age of $10 \mathrm{mo}$, and a similar thoracotomy was used as a sham operation. Three dogs were lost during the follow-up: two coarcted (one heart failure, one ruptured intercostal artery) and one control (cardiac tamponade during catheterization). The final analysis 1 y after the coarctation repair was based on eight aortoplasty and seven control dogs. The dogs were fed normal dog food (Astra Evos Pris; Evos, Sōdertālje, Sweden). The animal experimentation was performed with the highest standards of humane care, and the experimentation program was approved by the Committee on Animal Experimentation in the University of Oulu.

The systolic pressure gradient (peak-to-peak) across the coarctation was $6.0(0.7) \mathrm{kPa}$ at rest before the aortoplasty (17), and the resting gradients $1 \mathrm{y}$ after coarctation repair were similar in both groups $[0.5(1.0) \mathrm{kPa}$ in the aortoplasty group and $0.0(0.1)$ $\mathrm{kPa}$ in the control group] (18). The aortoplasty reduced aortic systolic blood pressure from $20.4(2.5)$ to $16.3(2.2) \mathrm{kPa}$. Twelve mo after coarctation repair, a perfusion fixation was performed with a fixative containing $2 \%$ glutaraldehyde in $0.1 \mathrm{M}$ sodium phosphate buffer ( $\mathrm{pH} 7.5)$ (2). Histologic specimens were taken from two sites in the aorta (between the brachiocephalic and left subclavian artery above the coarctation site and $1.5 \mathrm{~cm}$ distal to the aortoplasty) and two sites in the coronary arteries (left anterior descending and circumflexing arteries). The specimens were carefully embedded in paraffin in a perpendicular position. Light microscopic morphometry was performed with an ocular micrometer on 5- $\mu \mathrm{m}$ sections stained with Verhoeff's elastica. The medial and intimal thicknesses of the vessel walls were measured from 10 random light microscopy fields at a magnification of $100 \times$. A magnification of $40 \times$ was used to measure the coronary arterial diameters. Hematoxylin-eosin stained sections were used for qualitative analysis.

Comparisons of group means are based on a two-tailed $t$ test with a $p<0.05$ denoting statistical significance. The data are presented as means (SD). 
Table 1. Morphometric data on aorta and coronary arteries of aortoplasty group $(n=8)$ and control group $(n=7)$ 12 mo after coarctation repair

\begin{tabular}{|c|c|c|c|c|}
\hline & $\begin{array}{c}\text { Aortoplasty } \\
\text { [mean (SD)] }\end{array}$ & $\begin{array}{c}\text { Control } \\
{[\text { mean }(\mathrm{SD})]}\end{array}$ & $\begin{array}{c}\text { Confidence } \\
\text { intervals* }\end{array}$ & $p$ \\
\hline \multicolumn{5}{|l|}{ Proximal aorta } \\
\hline Intimal thickness $(\mu \mathrm{m})$ & $53.2(13.3)$ & $38.3(10.9)$ & $1.20-28.6$ & 0.05 \\
\hline \multicolumn{5}{|l|}{ Distal aorta } \\
\hline Intimal thickness $(\mu \mathrm{m})$ & $32.1(10.4)$ & $28.2(9.8)$ & $-7.42-15.2$ & \\
\hline Medial thickness (mm) & $1.40(0.12)$ & $1.37(0.10)$ & $-0.09-0.15$ & \\
\hline Medial thickness $(\mu \mathrm{m})$ & $141(33)$ & $129(24)$ & $-20.6-44.6$ & \\
\hline External diameter (mm) & $1.66(0.15)$ & $1.58(0.10)$ & $-0.07-0.23$ & \\
\hline Internal thickness (mm) & $1.37(0.11)$ & $1.32(0.13)$ & $-0.08-0.18$ & \\
\hline \multicolumn{5}{|c|}{ Left anterior circumflexing coronary artery } \\
\hline Intimal thickness $(\mu \mathrm{m})$ & $15.2(4.1)$ & $14.5(3.4)$ & $-3.54-4.94$ & \\
\hline Medial thickness $(\mu \mathrm{m})$ & $149(38)$ & $137(26)$ & $-24.9-48.9$ & \\
\hline External diameter (mm) & $1.73(0.20)$ & $1.68(0.17)$ & $-0.16-0.26$ & \\
\hline
\end{tabular}

* Confidence intervals $=95 \%$ confidence intervals for the differences between the aortoplasty and control groups.

\section{RESULTS}

The medial and intimal thicknesses of the proximal aorta 1.5 $\mathrm{cm}$ above the aortoplasty site were greater in the aortoplasty group than in the control group [medial $1.86(0.06)$ versus 1.76 $(0.08) \mathrm{mm}, p<0.05$; intimal $53.2(13.3)$ versus $38.3(10.9) \mu \mathrm{m}$, $p<0.05]$. The intimal thickening was diffuse, and no fatty streaks or other clear atherosclerotic lesions were found. Although all the intimal and medial thicknesses of the left anterior descending and circumflexing coronary arteries tended to be greater in the aortoplasty group, there were no statistically significant differences in the findings in light microscopy (Table 1). The external and internal diameters of the coronary arteries were at the same level in both groups.

\section{DISCUSSION}

Although the coarctation was produced here at the age of 2 mo and repaired $8 \mathrm{mo}$ later, the proximal aortic medial and intimal thicknesses were increased in the aortoplasty group 12 mo after the repair. Similar long-term medial thickening also occurs in hypertensive rats $(9,19)$. Medial and intimal thickening of the coronary artery wall are typical lesions in coarcted monkeys, reversing partially after antihypertensive treatment (1). Fibromusculoelastic intimal thickening may be an initial lesion of atherosclerosis, but fatty streaks (intimal accumulation of lipids associated with an increase in intimal cells) are the first gross evidence of atherosclerosis (20). The intimal lesions seen in dogs are of a sclerotic nature and consist of diffuse intimal thickenings, raised streaks, and plaque formation (21). Atherosclerotic lesions are quite difficult to produce in dogs $(21,22)$, and this may be the reason why no more severe histologic changes of this kind were found.

The thickening of the vascular wall reduces the compliance of the vascular bed above the coarctation site and increases the systolic blood pressure by increasing the aortic input impedance during the ejection phase. This may cause the exaggerated blood pressure rise during exercise and serve to maintain the left ventricular hypertrophy after coarctation repair $(13,14,23,24)$.

In an earlier experiment, coarcted dogs had significantly thickened media of the coronary arteries $7 \mathrm{mo}$ after induction of coarctation by the same method (2). In the present series, the intimal and medial thicknesses of the coronary artery wall tended to be greater in the aortoplasty group, but the difference did not reach statistical significance. The reversibility of the hypertensive changes in the coronary vessels may be better than in the aorta. Short-term renal hypertension $(8 \mathrm{wk})$ in rats causes medialintimal hypertrophy in the thoracic and abdominal aorta (10), which is only partially reversed within $4 \mathrm{wk}$ of removing the renal artery clip.

In this animal model, adequate coarctation repair at the age of 10 mo was too late to prevent the observed vascular changes resulting from high blood pressure before the aortoplasty. It is these changes that may explain the complications observed after coarctation repair in man $(13,14)$. The changes probably diminish with earlier repair (19) or antihypertensive drug therapy (25), but aortic coarctation may cause vascular changes even during the perinatal period.

\section{REFERENCES}

1. Hollander W, Madoff I, Paddoc J, Kirkpatrick B 1976 Aggravation of atherosclerosis by hypertension in a subhuman primate model with coarctation of the aorta. Circ Res 38(suppl II):II-63-II-72

2. Uhari M, Tarkka M, Reinilä A, Heikkinen E 1982 Morphology of the great arteries in chronic experimental coarctation in dogs. Br J Exp Pathol 63 369-377

3. Vlodaver Z, Neufeld HN 1968 The coronary arteries in coarctation of the aorta. Circulation 37:449-454

4. Anyanwu E, Dittrich H, Jelesijevic V, Drüen B, Krefting ER, Höhling H 1981 Coarctation of the aorta. A risk factor in children for the development of arteriosclerosis. Arteriosclerosis 39:367-381

5. Schneeweiss A, Sherf L, Lehrer E, Lieberman Y, Neufeld HN 1982 Segmental study of the terminal coronary vessel in coarctation of the aorta: a natural model for study of the effect of coronary hypertension on human coronary circulation. Am J Cardiol 49:1996-2002

6. Wolinsky H 1972 Long-term effects of hypertension on the rat aortic wall and their relation to concurrent aging changes. Circ Res 30:301-309

7. Ooshima A, Fuller GC, Cardinale GJ, Spector S, Udenfriend S 1974 Increased collagen synthesis in blood vessels of hypertensive rats and its reversal by antihypertensive agents. Proc Natl Acad Sci USA 71:3019-3023

8. Lundgren Y 1974 Regression of structural cardiovascular changes after reversal of experimental renal hypertension in rats. Acta Physiol Scand 91:275-285

9. Wolinsky H 1971 Effects of hypertension and its reversal on the thoracic aorta of male and female rats. Circ Res 28:622-637

10. Stacy DL, Prewitt RL 1989 Effects of chronic hypertension and its reversal on arteries and arterioles. Circ Res 65:869-879

11. Maron BJ, Humpries JO, Rowe RD, Mellits ED 1973 Prognosis of surgically corrected coarctation of the aorta. A 20 -year postoperative appraisal. Circulation 47:119-126

12. Presbitero P, Demarie D, Villani M, Actis Perinetto $M$, Riva G, Orzan $F$ Bobbio M, Morea M, Brusca A 1987 Long term results (15-30 years) of surgical repair of aortic coarctation. Br Heart J 57:462-467

13. O'Rourke M 1990 Coupling between the left ventricle and arterial system in hypertension. Eur Heart J 11(suppl G):24-28

14. Pannier BM, London GM, Cuche J-L, Girerd X, Safar ME 1990 Physical properties of the aorta and cardiac hypertrophy in essential hypertension. Eur Heart J 11(suppl G):17-23

15. Tarkka M, Uhari M, Koskinen M, Heikkinen E 1982 Experimental aortic coarctation in puppies. J Surg Res 33:208-213

16. Leskinen M, Tarkka M, Reinilä A, Uhari M 1991 Venous patch aortoplasty as a method for experimental coarctation repair. Scand I Thorac Cardiovasc Surg 25:107-110 
17. Leskinen M 1991 Left ventricular responses to experimental aortic coarctation in growing puppies. Acta Physiol Scand 141:391-398

18. Leskinen M, Tarkka M, Uhari M, Kettunen R 1991 Left ventricular function in dogs 1 year after coarctectomy. Pediatr Cardiol 12:150-154

19. Weiss L 1974 Long-term treatment with antihypertensive drugs in spontaneously hypertensive rats (SHR). Effect on blood pressure, survival rate and cardiovascular design. Acta Physiol Scand 91:393-409

20. National Heart and Lung Institute Task Force on Arteriosclerosis 1971 Arteriosclerosis. Department of Health, Education and Welfare, Washington, DC, publication no. 72-219, pp 1-364

21. Luginbühl H, Jones JET, Detweiler DK 1976 The morphology of spontaneous arteriosclerotic lesions in the dog. In: Roberts JC, Straus R (eds) Comparative atherosclerosis. Hoeber, Harper and Row, New York, pp 161-169
22. Armstrong ML, Heistad DD 1990 Animal models of atherosclerosis. Atherosclerosis $85: 15-23$

23. Pelech AN, Kartodihardjo W, Balfe JA, Balfe JW, Olley PM, Leenen FHH 1986 Exercise in children before and after coarctectomy: hemodynamic, echocardiographic, and biochemical assessment. Am Heart J 112: $1263-1270$

24. Simsolo R, Grunfeld B, Gimenez M, Lopez M, Berri G, Becu L, Barontini M 1988 Long-term systemic hypertension in children after successful repair of coarctation of the aorta. Am Heart J 115:1268-1273

25. Uhari M, Reinilä, Tarkka M 1983 Prevention of morphological changes of great arteries in coarctation of the aorta with antihypertensive therapy. $\mathrm{Br} J$ Exp Pathol 64:191-197

\section{Announcement}

\section{Annual Meetings}

The American Pediatric Society, The Society for Pediatric Research, and The Ambulatory Pediatric Association will hold their annual meetings May 4-7, 1992 at the Baltimore Convention Center, Baltimore, MD. For further information, contact: APS/SPR Association Headquarters, 141 Northwest Point Blvd., P.O. Box 675, Elk Grove Village, IL 60009-0675, (708)427-0205, FAX (708)427-1305 or Ambulatory Pediatric Association, 6728 Old McLean Village, McLean, VA 22101, (703)556-9222. 